\title{
Biocidal Activities of a New Type of Polysaccharide (Extract from Egyptian Aloe Vera)-Based Cationic Schiff Bases Surfactant and Their Metal Complexes
}

\author{
Mostafa E. Hendawy ${ }^{1,}$, Mohammed F. Zaky ${ }^{2}$, Abdelfattah M. Badawi ${ }^{2}$, Ibrahim A. Sabbah ${ }^{1}$ \\ ${ }^{1}$ Chemistry Department, Faculty of Science, Al-Azhar University, Cairo, Egypt \\ ${ }^{2}$ Petrochemicals Department, Egyptian Petroleum Research Institute, Cairo, Egypt
}

Email address:

mostafaeid97@yahoo.com (M. E. Hendawy)

${ }^{*}$ Corresponding author

\section{To cite this article:}

Mostafa E. Hendawy, Mohammed F. Zaky, Abdelfattah M. Badawi, Ibrahim A. Sabbah. Biocidal Activities of a New Type of Polysaccharide (Extract from Egyptian Aloe Vera)-Based Cationic Schiff Bases Surfactant and Their Metal Complexes. Petroleum Science and Engineering. Vol. 2, No. 1, 2018, pp. 37-43. doi: 10.11648/j.pse.20180201.16

Received: April 1, 2018; Accepted: April 19, 2018; Published: May 19, 2018

\begin{abstract}
Five series of cationic polysaccharide Schiff bases surfactant $\left[\mathrm{AQ}_{10-18}\right]$ were synthesized by the reaction between different five Schiff bases (which prepared by condensation of fatty amine namely: decyl, dodecyl, tetradecyl, hexadecyl and octadecyl amine and 4-pyridine carboxaldehyde) and polysaccharide sulfate as quaternizing agent. Also, their complexes with different transition metals including $\mathrm{Ni}^{2+}, \mathrm{Co}^{2+}, \mathrm{Cu}^{2+}$ and $\mathrm{Fe}^{3+}$ were synthesized. The chemical structures of these surfactants were confirmed using elemental analysis, FTIR spectra, UV spectra, 1H-NMR and atomic absorption spectroscopy. The studied surfactants were evaluated as antimicrobial agents against pathogenic and sulfate reducing bacteria using inhibition zone diameters. The synthesized cationic polysaccharide Schiff bases surfactant showed good antimicrobial activities against the tested microorganisms including Gram positive, Gram negative, yeast and fungi. The effect of the structure of these cationic surfactants and their metal complexes of $\mathrm{Ni}^{2+}, \mathrm{Co}^{2+}, \mathrm{Cu}^{2+}$ and $\mathrm{Fe}^{3+}$ on the cell membrane is discussed as well as their potent action on the targeted bacteria, yeast and fungi.
\end{abstract}

Keywords: Antimicrobial Activity, Carbohydrate Esters, Cationic Surfactants, Polysaccharide Schiff Bases Surfactant, Biocidal Activity

\section{Introduction}

An important class of cationic surfactants is the quaternary ammonium salt which is used within specialized areas such as fabric softeners, hair conditioners, and antimicrobial agents [1, 2]. Unfortunately, most quaternary ammonium cationics available today share some common disadvantages limiting their use. First of all, they show a poor compatibility with other materials, because exposure to anionic surfactants and soaps inhibits their action by forming insoluble complexes [3]. The mode of action of quaternary ammonium compounds on microorganism destruction includes denaturizing of proteins and interference with glycolysis. This causes membrane damage and also alters the vital permeability features of the cell structure. The similarity in chemical structure of quaternary ammonium compounds and cellular constituents enhances their destructive action towards microorganisms. Co-ordination compounds exhibit different characteristic properties which depend on the metal ion to which they are bound, the nature of the metal as well as the type of ligand, etc. These metal complexes have found extensive applications in various fields of human interest. The nature of a coordination compound depends on the metal ion and the donor atoms, as well as on the structure of the ligand and the metal-ligand interaction [4].

Natural occurring compounds are those compounds which occur in different organisms, animals, plants or microorganisms. These compounds are different and widely spread in the plant and animal kingdoms. One of the most widespread compounds in the plant kingdom is polysaccharide which extracted from Egyptian aloe vera. In this study, naturally occurring polysaccharide was chemically modified into cationic surface active agents containing 
hydrocarbon chains with different lengths. The biocidal activity of the produced cationic polysaccharide derivatives and their metal complexes were determined.

\section{Materials and Methods}

\subsection{Chemicals}

Fatty amines (decyle amine, dodecyle amine, tetradecyle amine, hexadecyle amine and octadecyle amine) were purchased from Sigma (99\%), aldehydes (4-pyridine carboxaldehyde) purchased from (Aldrich, 97\%), Sulfuric acid (ADWIC, 99\%), Di methyl formamide (ADWIC, 99\%), ethyl alcohol (ADWIC, 99\%), Nickel Chloride (BDH, AR), Cobalt Chloride (BDH, AR), Ferric Chloride (BDH, AR), Copper Sulfate (BDH, AR).

\subsection{Instrumentation}

Elemental analysis: Vario Elementar Analyzer; IR spectroscopy: Perkin Elmer FTIR System (Genesis Fourier Transformer FTIR ${ }^{\mathrm{TM}}$ ) in the $4000-400 \mathrm{~cm}^{-1}$ region using $\mathrm{KBr}$ disks; ${ }^{+} \mathrm{H}-\mathrm{NMR}$ spectroscopy: Varian NMR-300, Mercury $300 \mathrm{MHz}$ spectrometers in $\mathrm{CDCl}_{3}$ solvent and TMS as internal standard and the chemical shifts reported in $\delta(\mathrm{ppm})$; Ultra violet Perkin-Elmer S52 spectrophotometer.

\subsection{Synthesis}

\subsubsection{Synthesis of Cationic Surfactants of Schiff Base Derivatives}

Cationic form of the synthesized Schiff bases were obtained throughout direct interaction between equimolar ratios of the synthesized Schiff bases (which prepared by condensation of fatty amines namely: decyl, dodecyl, tetradecyl, hexadecyl and octadecyl amine and 4-pyridine carboxaldehyde) and polysaccharide sulfate as quaternizing agent. The reaction mixture was refluxed for (12-24) hours, and then left overnight for complete precipitation of the cationic quaternary ammonium compounds. The product was filtered and recrystallized for three times from ethanol to produce the pure cationic Schiff base surfactants $A Q_{10}, A Q_{12}$, $A Q_{14}, A Q_{16}$ and $A Q_{18}$ [5], Figure 1.

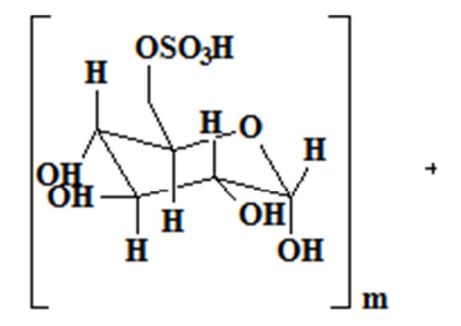

$$
\mathbf{m}=\text { number of rep eating units }
$$
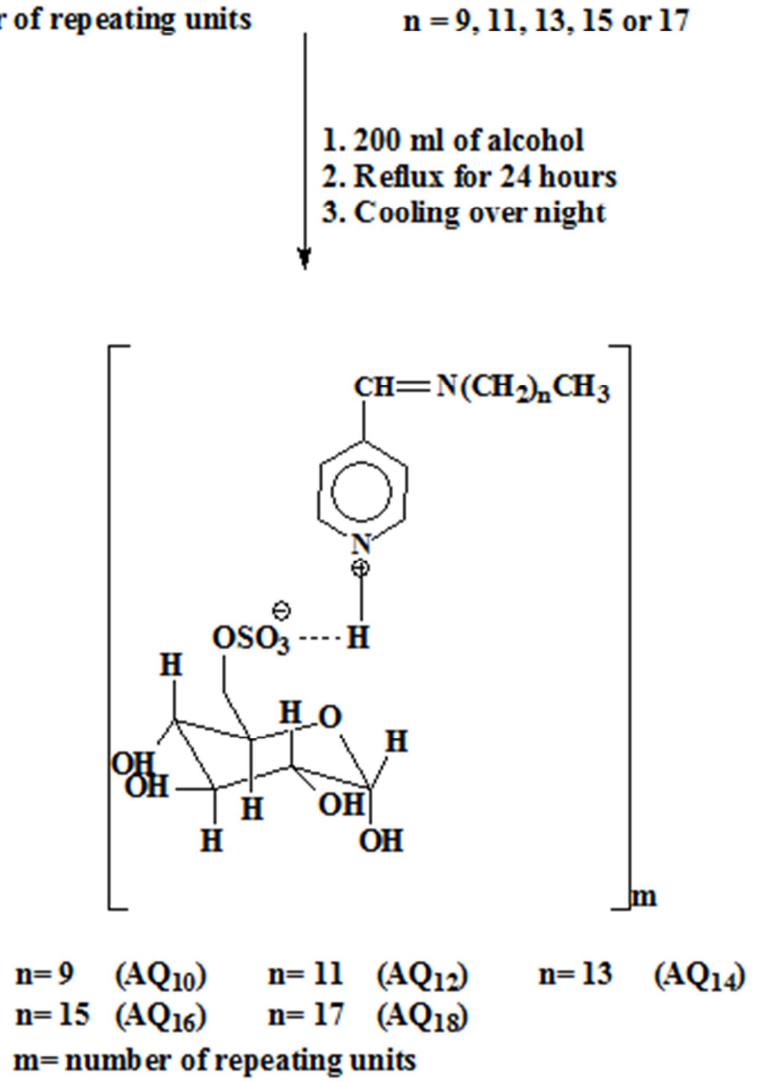

Figure 1. Synthesis of cationic surfactants of Schiff base derivatives. 


\subsubsection{Synthesis of Transition Metal Complexes of Cationic} Schiff Base Amphiphiles

All the metal complexes were synthesized by following general procedure. The corresponding metal salt $\left(\mathrm{NiCl}_{2}\right.$, $\mathrm{CoCl}_{2}, \mathrm{FeCl}_{3}, \mathrm{CuSO}_{4}$ ) and appropriate amount of cationic Schiff base amphiphiles in 1:2 molar ratios (in case of $\mathrm{Ni}^{2+}$,
$\left.\mathrm{Co}^{2+}, \mathrm{Cu}^{2+}\right)$ and in 1:3 molar ratio in case of $\left(\mathrm{Fe}^{3+}\right)$ were dissolved in ethanol and refluxed for 6 hours. On cooling at room temperature, cationic Schiff base metal complexes were precipitated. The products were filtered under suction, washed with cold ethanol and finally with anhydrous diethyl ether and kept in a desiccator over fused $\mathrm{CaCl}_{2}$ [6], Figure 2.

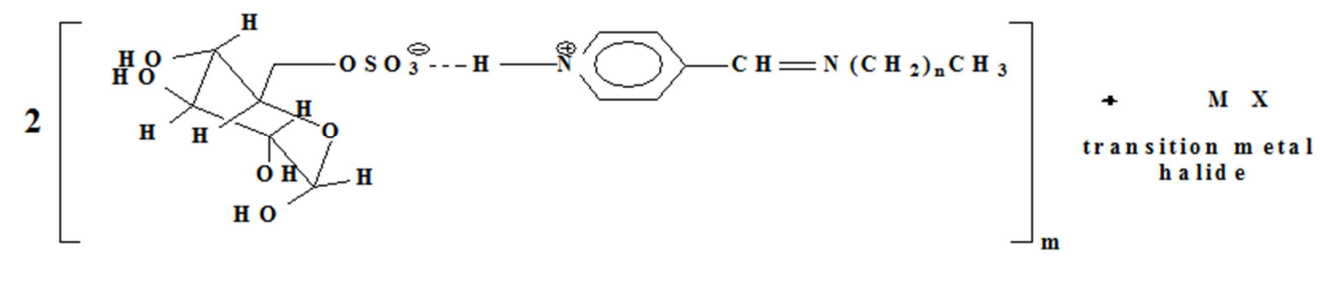

$\mathrm{n}=9,11,13,15$ a nd 17
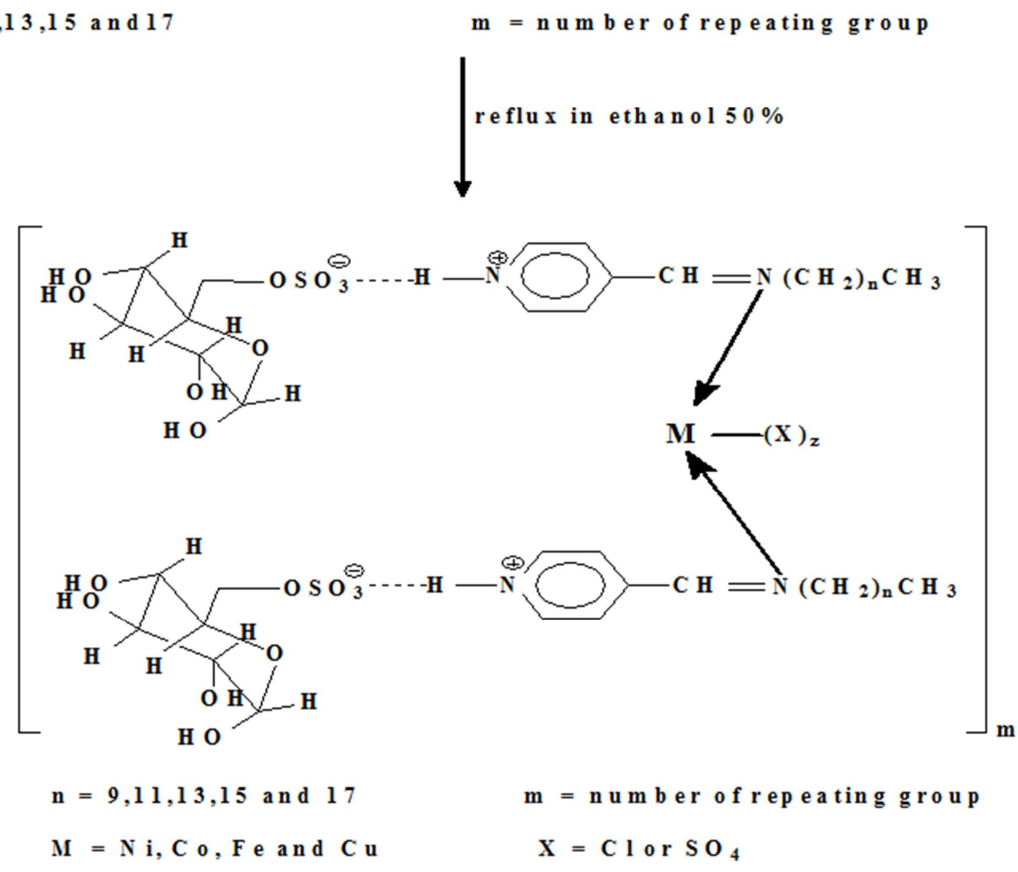

$\mathrm{AQ}_{10} \mathrm{Ni}(\mathrm{M}=\mathrm{Ni}, \mathrm{X}=\mathrm{Cl}, \mathrm{z}=2$ and $\mathrm{n}=9)$ $\mathrm{AQ}_{10} \mathrm{Fe}(\mathrm{M}=\mathrm{Fe}, \mathrm{X}=\mathrm{Cl}, \mathrm{z}=3$ and $\mathrm{n}=9)$

$\mathrm{AQ}_{12} \mathrm{Ni}(\mathrm{M}=\mathrm{Ni}, \mathrm{X}=\mathrm{Cl}, \mathrm{z}=2$ and $\mathrm{n}=11)$ $\mathrm{AQ}_{12} \mathrm{Fe}(\mathrm{M}=\mathrm{Fe}, \mathrm{X}=\mathrm{Cl}, \mathrm{z}=3$ and $\mathrm{n}=11)$

$\mathrm{AQ}_{14} \mathrm{Ni}(\mathrm{M}=\mathrm{Ni}, \mathrm{X}=\mathrm{Cl}, \mathrm{z}=2$ and $\mathrm{n}=13)$ $\mathrm{AQ}_{14} \mathrm{Fe}(\mathrm{M}=\mathrm{Fe}, \mathrm{X}=\mathrm{Cl}, \mathrm{z}=3$ and $\mathrm{n}=13)$

$\mathrm{AQ}_{16} \mathrm{Ni}(\mathrm{M}=\mathrm{Ni}, \mathrm{X}=\mathrm{Cl}, \mathrm{z}=2$ and $\mathrm{n}=15)$ $\mathrm{AQ}_{16} \mathrm{Fe}(\mathrm{M}=\mathrm{Fe}, \mathrm{X}=\mathrm{Cl}, \mathrm{z}=3$ and $\mathrm{n}=15)$

$\mathrm{AQ}_{18} \mathrm{Ni}(\mathrm{M}=\mathrm{Ni}, \mathrm{X}=\mathrm{Cl}, \mathrm{z}=2$ and $\mathrm{n}=17)$ $\mathrm{AQ}_{18} \mathrm{Fe}(\mathrm{M}=\mathrm{Fe}, \mathrm{X}=\mathrm{Cl}, \mathrm{z}=3$ and $\mathrm{n}=17)$
$\mathrm{AQ}_{10} \mathrm{Co}(\mathrm{M}=\mathrm{Co}, \mathrm{X}=\mathrm{Cl}, \mathrm{z}=2$ and $\mathrm{n}=9)$

$\mathrm{AQ}_{10} \mathrm{Cu}\left(\left(\mathrm{M}=\mathrm{Cu}, \mathrm{X}=\mathrm{SO}_{4}, \mathrm{z}=1\right.\right.$ and $\left.\mathrm{n}=9\right)$

$\mathrm{AQ}_{12} \mathrm{Co}(\mathrm{M}=\mathrm{Co}, \mathrm{X}=\mathrm{Cl}, \mathrm{z}=2$ and $\mathrm{n}=11)$

$\mathrm{AQ}_{12} \mathrm{Cu}\left(\left(\mathrm{M}=\mathrm{Cu}, \mathrm{X}=\mathrm{SO}_{4}, \mathrm{z}=1\right.\right.$ and $\left.\mathrm{n}=11\right)$

$\mathrm{AQ}_{14} \mathrm{Co}(\mathrm{M}=\mathrm{Co}, \mathrm{X}=\mathrm{Cl}, \mathrm{z}=2$ and $\mathrm{n}=13)$

$\mathrm{AQ}_{14} \mathrm{Cu}\left(\left(\mathrm{M}=\mathrm{Cu}, \mathrm{X}=\mathrm{SO}_{4}, \mathrm{z}=1\right.\right.$ and $\left.\mathrm{n}=13\right)$

$\mathrm{AQ}_{16} \mathrm{Co}(\mathrm{M}=\mathrm{Co}, \mathrm{X}=\mathrm{Cl}, \mathrm{z}=2$ and $\mathrm{n}=15)$

$\mathrm{AQ}_{16} \mathrm{Cu}\left(\left(\mathrm{M}=\mathrm{Cu}, \mathrm{X}=\mathrm{SO}_{4}, \mathrm{z}=1\right.\right.$ and $\left.\mathrm{n}=15\right)$

$\mathrm{AQ}_{18} \mathrm{Co}(\mathrm{M}=\mathrm{Co}, \mathrm{X}=\mathrm{Cl}, \mathrm{z}=2$ and $\mathrm{n}=17)$

$\mathrm{AQ}_{18} \mathrm{Cu}\left(\left(\mathrm{M}=\mathrm{Cu}, \mathrm{X}=\mathrm{SO}_{4}, \mathrm{z}=1\right.\right.$ and $\left.\mathrm{n}=17\right)$

Figure 2. Synthesis of transition metal complexes of cationic Schiff base Amphiphiles.

\section{Analyses}

Microelemental analyses were done using Vario Elementar instrument, FTIR spectroscopic analyses were done using Fourier-transform infrared spectrophoto-meter, ${ }^{1} \mathrm{H}-\mathrm{NMR}$ spectroscopic analyses were done using Bruker model DRX300 NMR spectrometer with TMS as an internal standard and atomic absorption spectroscopy (AAS) were done using Hitachi 180/80 atomic absorption spectrometer.

\section{Results and Discussion}

\subsection{Chemical Structure}

Chemical structure of the synthesized cationic Schiff bases 
surfactant and their metal complexes were confirmed using elemental analyses, FTIR spectroscopy, ${ }^{1} \mathrm{H}-\quad$ NMR spectroscopy and UV spectra as follows:

\subsubsection{Elemental Analyses}

The elemental analysis of the synthesized Schiff base and cationic Schiff base amphiphiles showed that the expected and found values of the different elements are very close to each other, indicating the purity of the synthesized compound.

\subsubsection{FTIR Spectroscopy}

a. The IR spectra of polysaccharide sulfate showed a broad band at $3420 \mathrm{~cm}^{-1}$ corresponding to $\mathrm{OH}$ alcohol group. Also band at $2927 \mathrm{~cm}^{-1}$ and also band at $1060 \mathrm{~cm}^{-1}$ corresponding to ether group. These entire previous bands characteristic the polysaccharide. There are two bands at $1152 \mathrm{~cm}^{-1}$ and 612 $\mathrm{cm}^{-1}$ corresponding to $\mathrm{S}=\mathrm{O}$ and $\mathrm{S}-\mathrm{O}$ respectively which indicate the presence of sulfonate group.

b. The IR spectra of Schiff bases compound showed complete disappearance of the absorption band at $\mathrm{v}_{\mathrm{C}=\mathrm{O}}$ at $1735 \mathrm{~cm}^{-1}$ and also the appearance of a new sharp band at $v_{\mathrm{C}=\mathrm{N}}$ at $1635-1660 \mathrm{~cm}^{-1}$. That indicates the completion of the condensation reaction between the fatty amines and 4pyridine carboxaldehyde. The IR spectra of the synthesized Schiff base compounds showed two characteristic bands at $2920 \mathrm{~cm}^{-1}$ and $2850 \mathrm{~cm}^{-1}$ corresponding to the stretching of the methylene groups $\left(\mathrm{CH}_{2}\right)$ and also the methyl groups $\left(\mathrm{CH}_{3}\right)$, respectively, corresponding to the alkyl chains of the fatty amines. Also, a broad band at $935-987 \mathrm{~cm}^{-1}$ was appeared characterized the $(\mathrm{C}-\mathrm{H})$ stretching of the aromatic pyridine nucleus in the synthesized compounds.

c. The IR spectra of compounds $\left(\mathrm{AQ}_{10}, \mathrm{AQ}_{12}, \mathrm{AQ}_{14}, \mathrm{AQ}_{16}\right.$ and $\left.A Q_{18}\right)$ showed two specific bands were appeared at 3130 $\mathrm{cm}^{-1}$ and $1450 \mathrm{~cm}^{-1}$ corresponding to the vibration and elongation of $\left[\mathrm{N}^{+}\right]$group.

\subsection{3. ${ }^{1} \mathrm{H}$ - NMR Spectroscopy}

The ${ }^{1} \mathrm{H}$ - NMR spectroscopic analysis were performed for polysaccharide (aloe) to determine their actual structure. It showed the following signals:

The published data concerning NMR spectra of polysaccharide extracted from Aloe represent several characteristic signals at: $\delta(\mathrm{ppm})=1.2,1.4,1.8,2.2,3,3.4$, $3.6,3.8,4.2,4.6,5$ and $5.2 \mathrm{ppm}$. That is due to the complex structure of the polysaccharide.

The extracted polysaccharide form the Egyptian Aloe Vera was analyzed by NMR spectra and showed the following spectra: $\delta(\mathrm{ppm})=1.2 \mathrm{pm}, 2.1 \mathrm{ppm}, 4.2 \mathrm{ppm}, 3.8 \mathrm{ppm}$ and 3.6 ppm. That is in a good agreement with the published data [78]. Some signals were disappeared due to the differences of the substituents in the chemical structures of the two types of the polysaccharides.

The NMR spectra of the synthesized cationic Schiff base surfactant (representatively for $\mathrm{AQ}_{12}$ ), showed the appearance of additional two signals at $\delta(\mathrm{ppm})=0.88 \mathrm{ppm}$ and 3.38 ppm. These two characteristic signals are assigned to the terminal methyl group of the fatty amine moieties $\left(\mathrm{CH}_{3}\right)$ and the second at $3.38 \mathrm{ppm}$ is assigned for the azomethine proton $(-\mathrm{CH}=\mathrm{N}-)$. The figure also showed increase in the integration of the signal at $1.2 \mathrm{ppm}$, which is attributed to the presence of the methylene groups of the fatty amine moiety $\left(\mathrm{CH}_{2}\right)_{n}$.

The data obtained from the NMR spectra proved the chemical structures of the synthesized surfactants as represented in Figure 1.

\subsubsection{UV Spectra}

UV spectra were recorded with a Perkin-Elmer S52 spectrophotometer. The quaternization and complex formation was confirmed by the appearance of new bands in UV spectra. Table 1

Table 1. UV adsorption maxima of cationic polysaccharide Schiff bases surfactant and their metal complexes.

\begin{tabular}{|c|c|c|c|}
\hline Compound & $\lambda_{\max }(\mathrm{nm})$ & Compound & $\lambda_{\max }(\mathrm{nm})$ \\
\hline $\mathrm{AQ}_{10}$ & $742.5,258.0,200.0$ & $\mathrm{AQ}_{16}$ & $254.0,229.5$ \\
\hline $\mathrm{AQ}_{10} \mathrm{Ni}$ & $743.5,257.0,229.5$ & $\mathrm{AQ}_{16} \mathrm{Ni}$ & $740.0,255.5,229.5$ \\
\hline $\mathrm{AQ}_{10} \mathrm{Co}$ & $739.0,256.5,229.5$ & $\mathrm{AQ}_{16} \mathrm{Co}$ & $738.5,255.5,229.5$ \\
\hline $\mathrm{AQ}_{10} \mathrm{Fe}$ & $739.0,255.0,229.0$ & $\mathrm{AQ}_{16} \mathrm{Fe}$ & $739.5,252.0,229.5$ \\
\hline $\mathrm{AQ}_{10} \mathrm{Cu}$ & $740.5,256.5,229.5$ & $\mathrm{AQ}_{16} \mathrm{Cu}$ & $739.0,255.5,229.0$ \\
\hline $\mathrm{AQ}_{12}$ & 258.0 & $\mathrm{AQ}_{18}$ & $739.5,255.5,229.5$ \\
\hline $\mathrm{AQ}_{12} \mathrm{Ni}$ & $546.0,256.0$ & $\mathrm{AQ}_{18} \mathrm{Ni}$ & $742.0,256.0,229.5$ \\
\hline $\mathrm{AQ}_{12} \mathrm{Co}$ & $739.0,203.0$ & $\mathrm{AQ}_{18} \mathrm{Co}$ & $257.0,229.5$ \\
\hline $\mathrm{AQ}_{12} \mathrm{Fe}$ & $739.5,254.0$ & $\mathrm{AQ}_{18} \mathrm{Fe}$ & $741.0,255.5,229.5$ \\
\hline $\mathrm{AQ}_{12} \mathrm{Cu}$ & $739.5,203.0$ & $\mathrm{AQ}_{18} \mathrm{Cu}$ & $740.5,256.0,229.5$ \\
\hline $\mathrm{AQ}_{14}$ & 202.0 & & \\
\hline $\mathrm{AQ}_{14} \mathrm{Ni}$ & $738.0,256.5,229.5$ & & \\
\hline $\mathrm{AQ}_{14} \mathrm{Co}$ & $738.0,255.5,222.5$ & & \\
\hline $\mathrm{AQ}_{14} \mathrm{Fe}$ & $740.5,258.0,229.5$ & & \\
\hline $\mathrm{AQ}_{14} \mathrm{Cu}$ & $739.5,262.0,229.0$ & & \\
\hline
\end{tabular}

\subsection{Measurements}

Antimicrobial activity of the synthesized cationic Schiff base surfactants and their metal complexes:

The synthesized cationic surfactants and their metal complexes were screened for their antimicrobial activity against bacteria and fungi using the agar-well-diffusion method [9-10]. The bacterial strains were cultured on a nutrient medium, while the fungi strains were cultured on a malt medium. For bacteria, the broth media were incubated for $24 \mathrm{~h}$. As for fungus, the broth media were incubated for approximately $48 \mathrm{~h}$, with subsequent filtering of the culture through a thin layer of sterile Sintered Glass G2 to remove 
mycelia fragments before the solution containing the spores was used for inoculation.

The bacterial cell membrane is composed of a thick wall containing many layers of peptidoglycan and Teichoic acids, which are glycerol ribitol (polyhydric alcohol) through a phosphorus bond surrounded by lipids of lipopolysaccharides and proteins [11-13]. It is believed from the recent studies on cationic surfactants that they have an excellent bactericidal activity [14], which depends on the hydrophobic chain length, the surface activity and the dosage of these cationics. The results of the biocidal activities of the synthesized aloe vera Schiff base surfactants (table 2), it is clear that $\mathrm{AQ}_{10}$ showed higher inhibition zones diameter than the blank (cetyl trimethyl ammonium bromide) for all bacterial, yeast and fungal strains but $\mathrm{AQ}_{12}, \mathrm{AQ}_{14}, \mathrm{AQ}_{16}$ and $\mathrm{AQ}_{18}$ showed lower inhibition zones diameter than the blank. The biocidal activity of these surfactants can explain according to the diffusion mechanism and the surface adsorption mechanism:

\section{1- Diffusion mechanism:}

The adsorbed Schiff base amphiphiles on the cellular membranes are ease the penetration of the nonpolar chains of these amphiphiles into these membranes. The charged head groups are also stabilized that penetration by the interaction with the charges on these membranes. These charged either negative or positive charge depending on the bacterial genera (gram +ve/gram -ve). These charges are appeared originally from the presence of teichoic acids or peptidoglycan in these membranes. The penetration of the hydrophobic chains within the bacterial or fungal cell membranes and the neutralization of their surface charge disturb their selective permeability towards the outer environment. That leads to the penetration of several components to the cellular cytoplasm including counter ions and combination occur with the Table 2. Antimicrobial activities in terms of inhibition zone diameter $(\mathrm{mm} / \mathrm{mg})$ of the synthesized cationic polysaccharide Schiff bases surfactant against gram positive, gram negative bacteria, yeast, fungi and Desulfomonas pigra.

\begin{tabular}{|c|c|c|c|c|c|c|c|}
\hline \multirow{3}{*}{ Compounds } & \multicolumn{4}{|l|}{ Bacteria } & \multirow{3}{*}{$\begin{array}{l}\text { Yeast } \\
\text { Candida } \\
\text { albicans }\end{array}$} & \multirow{3}{*}{$\begin{array}{l}\text { Fungi } \\
\begin{array}{l}\text { Aspergillus } \\
\text { niger }\end{array}\end{array}$} & \multirow{3}{*}{$\begin{array}{l}\text { Desulfomonas } \\
\text { pigra }\end{array}$} \\
\hline & \multicolumn{2}{|c|}{ Gram positive } & \multicolumn{2}{|l|}{ Gram negative } & & & \\
\hline & $\begin{array}{l}\text { Bacillus } \\
\text { subtilis }\end{array}$ & Micrococcus sp. & $\begin{array}{l}\text { Pseudomonas } \\
\text { aeruginosa }\end{array}$ & Sarcina sp. & & & \\
\hline Standard (CTAB) & 12.3 & 12.3 & 12.3 & 12.3 & 12.3 & 11.6 & 25 \\
\hline $\mathrm{AQ}_{10}$ & 25 & 42 & 24 & 48 & 25 & 30 & 14 \\
\hline $\mathrm{AQ}_{12}$ & 15 & 23 & 14 & 12 & 14 & 0 & 14 \\
\hline $\mathrm{AQ}_{14}$ & 12 & 18 & 15 & 20 & 0 & 0 & 14 \\
\hline $\mathrm{AQ}_{18}$ & 8 & 15 & 15 & 16 & 0 & 0 & 10 \\
\hline
\end{tabular}

On the other hand, the biocidal activities of the metal complexes of the synthesized cationics (Ni-complexes as representative sample) were found to increase remarkably compared with their parent cationics (Table 2); this could be attributed to the increase in their adsorption tendency at interface. Analyzing the potent action of the synthesized derivatives containing different metal ions $\left(\mathrm{Ni}^{2+}, \mathrm{Co}^{2+}, \mathrm{Fe}^{3}\right.$ and $\mathrm{Cu}^{2+}$ ) allows us to conclude that the atomic configuration of the metal ions has a considerable influence on the biocidal activities of these compounds (Table 3 ). The biological activity results in (Table 3 ) reveal that the activity was increased by increasing the ionic volume. The biocidal activity was (nucleic acids) DNA and RNA. Hence, the biological reactions disturbed which cause death for these microorganisms [15-16].

\section{2- Surface adsorption mechanism:-}

The adsorption of amphiphilic molecules on the outer cellular membrane of the microorganism due to their amphipathic characteristics. In addition, the similarity between the hydrophobic chains and the lipid layers and the building units of the cell membranes and the monosaccharide in these compounds facilitates that adsorption [17]. The adsorption of these molecules at the cellular membranes reaches its maximum extent at a higher dose $(5 \mathrm{mg} / \mathrm{mL})$, leading to a complete coverage of the membrane by the surfactant molecules, which are able to penetrate it. Furthermore, the positive charges in the cationic molecules neutralize the negative charges on the bacterial cell membranes. Accordingly, the selective permeability which characterizes the outer cellular membrane is completely lost. Hence, the vital transportation of essential components for cell bioreactions and activities is disturbed. This causes the death of these microorganisms. The high adsorption tendency of these cationics increases their penetration through the cellular membrane, with a boost in activity [18-19].

Table 2 revealed that the hydrophobic chain length of the cationic surfactants plays an important role in their biological activities against the targeted microorganisms. It is clear that increasing the hydrophobic chain length decreases the biocidal activity of these compounds. This could be related to the increase in their adsorption tendency upon decreasing their hydrophobic chain length. Several researchers have dealt with the mode of action of these types of compounds on different microorganisms [20, 21]. increased in the following sequence: $\mathrm{Cu}^{2+}>\mathrm{Co}^{2+}>\mathrm{Ni}^{2+}>\mathrm{Fe}^{+}$ This can be explained by the electronegativity and the atomic radii of these ions. $\mathrm{Ni}^{2+}, \mathrm{Co}^{2+}$, and $\mathrm{Fe}^{3+}$ ions are a smaller ion, which increases their attraction for the halogen atoms; hence their complexes with the ligands will be polar in nature. The polarity will restrict their penetration through the cellular membranes of the microorganisms. That limits the potent action on these cells. On the other hand, $\mathrm{Cu}^{2+}$ ion is a comparatively large ion and the distribution of the positive charges in its outer shell will decrease its electronegativity. Hence, its complexes with the parent cationics are neutral which facilitates their penetration through the cellular 
membrane and subsequently increases its biocidal activity [4].

Table 3. Antimicrobial activities in terms of inhibition zone diameter ( $\mathrm{mm} / \mathrm{mg}$ ) of the synthesized metal complexes of cationic polysaccharide Schiff bases surfactants against gram positive, gram negative bacteria, yeast, fungi and Desulfomonas pigra.

\begin{tabular}{|c|c|c|c|c|c|c|c|}
\hline \multirow{3}{*}{ Compounds } & \multicolumn{4}{|l|}{ Bacteria } & \multirow{3}{*}{$\begin{array}{l}\text { Yeast } \\
\text { Candida } \\
\text { albicans } \\
\end{array}$} & \multirow{3}{*}{$\begin{array}{l}\text { Fungi } \\
\text { Aspergillus niger }\end{array}$} & \multirow{3}{*}{$\begin{array}{l}\text { Desulfomonas } \\
\text { pigra }\end{array}$} \\
\hline & \multicolumn{2}{|c|}{ Gram positive } & \multicolumn{2}{|l|}{ Gram negative } & & & \\
\hline & $\begin{array}{l}\text { Bacillus } \\
\text { subtilis }\end{array}$ & $\begin{array}{l}\text { Micrococcus } \\
\text { sp. }\end{array}$ & $\begin{array}{l}\text { Pseudomonas } \\
\text { aeruginosa }\end{array}$ & Sarcina sp. & & & \\
\hline \multicolumn{8}{|l|}{$\mathrm{Ni}$-complexes } \\
\hline $\mathrm{AQ}_{10}-\mathrm{Ni}$ & 23 & 35 & 30 & 45 & 23 & 25 & 13 \\
\hline $\mathrm{AQ}_{12}-\mathrm{Ni}$ & 17 & 30 & 16 & 10 & 35 & 25 & 17 \\
\hline $\mathrm{AQ}_{14}-\mathrm{Ni}$ & 0 & 11 & 12 & 16 & 0 & 0 & 13 \\
\hline $\mathrm{AQ}_{18}-\mathrm{Ni}$ & 20 & 17 & 13 & 0 & 0 & 0 & 10 \\
\hline \multicolumn{8}{|l|}{ Co-complexes } \\
\hline $\mathrm{AQ}_{10}-\mathrm{Co}$ & 26 & 47 & 35 & 46 & 27 & 27 & 14 \\
\hline $\mathrm{AQ}_{12}-\mathrm{Co}$ & 20 & 40 & 20 & 10 & 0 & 15 & 18 \\
\hline $\mathrm{AQ}_{14}-\mathrm{Co}$ & 22 & 20 & 15 & 15 & 0 & 0 & 18 \\
\hline $\mathrm{AQ}_{16}-\mathrm{Co}$ & 21 & 20 & 15 & 20 & 0 & 0 & 12 \\
\hline $\mathrm{AQ}_{18}-\mathrm{Co}$ & 24 & 22 & 18 & 24 & 0 & 0 & 15 \\
\hline $\mathrm{AQ}_{10}-\mathrm{Fe}$ & 24 & 25 & 40 & 40 & 23 & 0 & 13 \\
\hline $\mathrm{AQ}_{12}-\mathrm{Fe}$ & 0 & 0 & 0 & 0 & 0 & 0 & 14 \\
\hline $\mathrm{AQ}_{14}-\mathrm{Fe}$ & 0 & 14 & 11 & 15 & 0 & 0 & 14 \\
\hline $\mathrm{AQ}_{16}-\mathrm{Fe}$ & 0 & 16 & 10 & 0 & 0 & 0 & 0 \\
\hline $\mathrm{AQ}_{18}-\mathrm{Fe}$ & 0 & 0 & 13 & 0 & 0 & 0 & 0 \\
\hline \multicolumn{8}{|l|}{$\mathrm{Cu}$-complexes } \\
\hline $\mathrm{AQ}_{10}-\mathrm{Cu}$ & 32 & 40 & 45 & 50 & 30 & 30 & 14 \\
\hline $\mathrm{AQ}_{12}-\mathrm{Cu}$ & 20 & 13 & 0 & 0 & 0 & 16 & 15 \\
\hline $\mathrm{AQ}_{14}-\mathrm{Cu}$ & 15 & 11 & 30 & 0 & 0 & 0 & 14 \\
\hline $\mathrm{AQ}_{16}-\mathrm{Cu}$ & 0 & 25 & 24 & 32 & 0 & 0 & 12 \\
\hline $\mathrm{AQ}_{18}-\mathrm{Cu}$ & 15 & 0 & 30 & 0 & 0 & 0 & 10 \\
\hline
\end{tabular}

\section{Conclusion}

The synthesized cationic Schiff bases surfactant and their metal complexes were tested against different strain of bacteria using inhibition zone diameters and showed good antimicrobial activities against the tested microorganisms. Antimicrobial activity of the parent cationic Schiff bases surfactant exhibited high efficiency against the tested microorganisms compared to the drug reference used (cetyltrimethylammonium bromide). The high antimicrobial activity of the parent cationic Schiff bases surfactant and their metal complexes can be referred to several factors including chemical structural factors and surface factors. Chemical structural factors including the type of polysaccharide extracted from Egyptian aloe Vera, the benzene ring nucleus, sulfate group and hydrophobic chain length. The surface factors include the effectiveness, efficiency, surface pressure and surface area.

When the hydrophobic chain length of the surfactant Schiff base decrease, the number of adsorbed surfactant molecules at the cell membrane interface increase. Hence, the positively attached head group on the bacterial cell membrane increased and therefore the biocidal activity of the synthesized cationic Schiff bases surfactant increase. Also, when the hydrophobic chain length decreases, the values of minimum surface area of these compounds decrease. Hence, the area at which the hydrophobic chains will penetrate is so small area. That leads to great influence of these chains up on penetration in a small area. As a result the synthesized cationic Schiff bases surfactant molecules which have shorter hydrophobic chain length are adsorbed by a high population and small area at the cellular membrane which will ease their penetration into the membrane and consequently increase their biocidal activity

Antimicrobial activity was strongly increased by Complexation of this cationic Schiff bases surfactant with $\mathrm{Cu}$ (II), Co (II), Ni (II) and Fe (III) ions. In general the biological activity of the Complexation cationic Schiff bases surfactant was increased by increasing the ionic volume, $\mathrm{Cu}^{2+}>\mathrm{Co}^{2+}>$ $\mathrm{Ni}^{2+}>\mathrm{Fe}^{+}$.

\section{References}

[1] Cox MF (1984) Surfactants, in Detergents and Cleaners, edited by Lange KF, Carl Hanser Verlag, Munich, 43-90

[2] Greek BF (1991) Sales of Detergents Growing Despite Recession, Chem. Eng. News 69:25-52

[3] Rubingh DN (1990) Surface-Active Cationic Compounds in Detergency, in Cationic Surfactants, edited by Rubingh DN and Holland PM, Marcel Dekker, Inc., New York, 469-507

[4] Zaky M. F (2010) Biocidal Activities of Cationic Surface Active Starch and Its Transition Metal Complexes against Different Bacterial Strains. J Surf Deterg 13: 255-260

[5] Negm NA, Elkholy YM, Ghuiba FM, Zahran MK, Mahmoud SA, Tawfik SM (2011) Benzothiazol-3-ium cationic Schiff base surfactants: synthesis, surface activity and antimicrobial applications against pathogenic and sulfur reducing bacteria in oil fields. J. Adsorp. Sci. Technol. 32:512-518 
[6] Zaky MF (2008) Surface, biocidal activity relationship of some new phosphate cationic surfactants and their metal complexes. Egypt J Chem 51:317-322

[7] Jiao P, Jia Q, Randel G, Diehl B, Weaver S, Milligan G (2010) Quantitative 1H-NMR Spectrometry Method for Quality Control of Aloe Vera Products. J. AOAC Int. 93:842-848

[8] http:|www.spectralservice.de

[9] Cooper RE (1972) The theory of antibiotic diffusion zones. In: Kavanageh FW (ed) Analytical microbiology. Academic Press, New York

[10] National Committee for Clinical Laboratory Standards (1997) Methods for dilution antimicrobial susceptibility tests for bacteria that grow aerobically. Approved standard M7-A4. National Committee for Clinical Laboratory Standards, Wayne

[11] Koch A (2003) Bacterial wall as target for attack. Clin Microbiol Rev 16:673-681

[12] DeSantis TZ, Hugenholtz P, Larsen N, Rojas M, Brodie EL, Keller K, Huber T, Dalevi D, Hu P, Andersen GL (2006) Greengenes, a chimera-checked 16S rRNA gene database and workbench compatible with ARB. Appl Environ Microbiol 72:5069-5072

[13] Walsh F, Amyes S (2004) Microbiology and drug resistance mechanisms of fully resistant pathogens. Curr Opin Microbiol $7: 439-446$

[14] Jamora C, Theodoraki MA, Malhotra V, Theodorakis EA (2001) Investigation of the biological mode of action of clerocidin using whole cell assays. Bioorg Med Chem 9:13651347

[15] EL-Sukkary MMA, Sayed NA, Aiad I, Helmy SM, EL-Azab WIM (2009) Aqueous solution properties, biodegradability, and antimicrobial activity of some alkylpolyglycosides surfactants, Tenside Surf. Det. 46:312-325

[16] Negm NA, Mohamed AS (2008) Synthesis, characterization and biological activity of sugar-based gemini cationic amphiphiles, J Surf Deterg 11:215-221

[17] Chernomordik I, Kozlov MM, Zimmerberg J (1995) Lipids in biological membrane fusion. J Membr Biol 146:1-13

[18] Saier MHJ (1987) Enzymes in metabolic pathways. A comparative study of mechanism, structure, evolution, and control. Harper \& Row, New York

[19] Jack DL, Yang NM, Saier MHJ (2001) The drug/metabolite transporter super family. Eur J Biochem 268:3620
[20] Jamora C, Theodoraki MA, Malhotra V, Theodorakis EA (2001) Investigation of the biological mode of action of clerocidin using whole cell assays. Bioorg Med Chem 9:13651374

[21] Ganzle M (2004) Extracellular homopolysaccharides and oligosaccharides from intestinal lactobacilli. Appl Microbiol Biotechnol 64:326-338

\section{Biography}

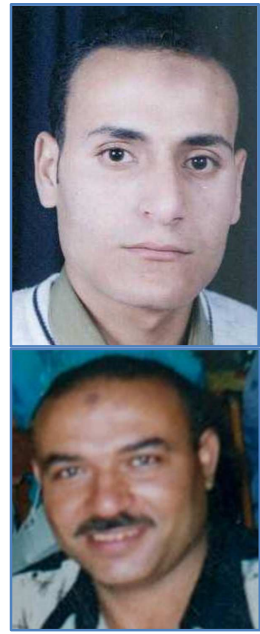

Mostafa Eid Hendawy is a Ph.D. student working as a chemist in the Foam Factory. His interests are in synthesis and applications of environmentally friendly compounds and their uses as biocides.

and biological activity.

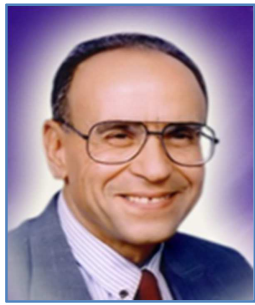

Abdelfattah Mohsen Badawi received his Ph.D. in applied organic chemistry from Alazhar University. $\mathrm{He}$ has completed courses on chemical warfare agents verification at Helsinki University (Finland) and the Institute of Applied Surfactant Research at Oklahoma University. Presently, he is a professor of applied organic chemistry at the Egyptian Petroleum Research Institute, Cairo, Egypt.

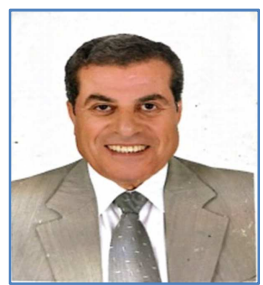

Ibrahim Abdelsalam Sabbah is a professor of organic chemistry, Chemistry department, Faculty of Science Alazhar University, Cairo, Egypt. 